\title{
Actions Ultra Vires Minister of State-Owned Enterprises in the Procurement of Goods and Services at Subsidiaries of State-Owned Enterprises
}

\author{
${ }^{1}$ Fauzan Prasetya ${ }^{*},{ }^{2}$ Busyra Azheri, ${ }^{3}$ Ismansyah, ${ }^{4}$ Sukanda Husin \\ ${ }^{1}$ Student of Doctoral Law Study Program, Postgraduate Program, Andalas University of Padang, Indonesia \\ ${ }^{2,3,4}$ Lecturer of Faculty of Law, Andalas University of Padang, Indonesia
}

\begin{abstract}
The Government through the Minister of State-Owned Enterprises (SOEs) in his position as a Shareholder in SOEs (Indonesian: Badan Usaha Milik Negara (BUMN) enacts the Minister of SOE Regulation Number: PER-15 / MBU / 2012 Regarding Amendments to the Regulation of the State Minister of StateOwned Enterprises Number PER-05 / MBU / 2008 Regarding Guidelines General Implementation of Procurement of Goods and Services of State-Owned Enterprises in SOE Subsidiaries. Which actions have raised the pros and cons of the capacity of the Minister of SOEs as BUMN shareholders in SOE subsidiaries. The legal status of BUMN subsidiaries in the BUMN holding scheme remains a separate legal entity that has their respective organs and responsibilities as regulated in the Law of PT. When the SOE Minister acts on behalf of the State, he is the shareholder of SOE as contained in Article 1 paragraph (1) of the BUMN Law. As a shareholder, the Minister of SOEs can only establish policies towards SOEs. Whereas in SOE Subsidiaries, the shareholders are SOEs as legal subjects. So that the provisions of Article 1 number (2) SOE Ministerial Regulation Number 3 of 2012 whereby the Minister of BUMN cannot act as a shareholder. The enactment of BUMN Permen 15/2012 to SOE Subsidiaries by SOEs Minister in his capacity as BUMN shareholder is an ultra vires action.
\end{abstract}

Keywords: The Minister of Soes, the Subsidiary of Soes, Ultra Vires

\section{Introduction}

The power of the state in determining the direction of the development of the Indonesian economy as mandated by the 1945 Constitution (hereinafter abbreviated to the 1945 Constitution), where Article 33 paragraph (2) emphasizes that "Production branches which are important for the state and which control the livelihoods of many people are claimed by Aasai by state "and Article 33 paragraph (3) confirms that" The earth and water and the natural resources contained therein are controlled by the state and are used for the greatest prosperity of the people ". done by forming certain business entities, one of which is a BUMN. Same is the case with Indonesia, countries in the world also put their country's wealth in SOEs as expressed by the OECD Guidelines on Corporate Governance of State-Owned Enterprises, giving the term BUMN referring to companies where the state has significant control, through full or significant majority ownership like Singapore.

In the 2005-2009 BUMN Revitalization Masterplan it is stated that the government will implement several strategic policies to improve performance, including restructuring SOEs in the form of holding. With the holding of a BUMN, an idea emerged within the BUMN to synergize in the process of procurement of goods and / or services. It is intended that the process of procuring goods and services can be carried out quickly, flexibly, competitively, efficiently and effectively without losing business momentum by making appointments between affiliated SOEs, between subsidiaries and holding companies (SE BUMN, 2009).

In 2012 the Ministry of SOEs issued a Regulation of the Minister of State-Owned Enterprises Number: PER-15 / MBU / 2012 Regarding Amendments to the Regulation of the State Minister of State-Owned Enterprises Number PER-05 / MBU / 2008 Regarding General Guidelines for the Implementation of Procurement of Goods and Services of State-Owned Enterprises State (hereinafter referred to as BUMN 
Decree Number 15 of 2012). Article 12 A paragraph (1) of this SOE Ministerial Regulation Number 15 of 2012 states that "This Ministerial Regulation of the State-Owned Enterprise is also applied to SOE Subsidiaries and SOE Affiliated Companies, the implementation of which is carried out in accordance with statutory provisions." The enactment of this regulation will affect SOE subsidiaries in the SOE holding scheme. Where in the conception of holding, the parent company cannot intervene in the subsidiary as an independent legal subject, let alone impose regulations issued by the Ministry of SOEs which are immediately related to the procurement of goods and services.

\section{Result and Discussion}

\subsection{State-Owned Enterprises and Regulations}

Indonesia as a state of law that puts forward the principle of welfare state, should ensure the implementation of various efforts to create prosperity for its people. This is in accordance with the basic idea of state objectives in the Preamble to the 1945 Constitution which states that the purpose of the state is to advance general welfare or in other formulations to realize social justice for all Indonesian people (Ridwan, 2006). Related to this, W. Friedman asserted that ideally a country acts in 3 (three) general dimensions, namely (Suhardi, 2007):

1. The state acts as a regulator (de stuurende) that controls or drives the economy in which the state acts as a referee (Jury);

2. The state acts as a provider (de presterende) more in a country which falsifies as a welfare state (Welfare state);

3. The state acts as an entrepreneur.

When it is related to the background of why a state-owned SOE is formed as an effort to achieve the government's goal for the welfare of its people (Suhardi, 2007). This is in line with the mandate of Article 33 of the 1945 Constitution which states that the existence of BUMN as one of the pillars of the Indonesian economy, in addition to private business entities and cooperatives. All of this is intended as the involvement and responsibility of the state in an effort to ensure that "branches of production which are important for the state and which control the lives of many people are controlled by the state and used as much as possible for the prosperity of the people". As referred to in Article 33 paragraph (3) of the 1945 Constitution. Thus it can be concluded that the existence of BUMN is a mandate of the constitution in an effort to realize the welfare and prosperity of the people in line with the concept of welfare state (Fuady, 2005).

The existence of BUMN has been regulated in such a way as Act Number 19 of 2003 concerning State Owned Enterprises (hereinafter abbreviated as BUMN Act), as a lex specialist and Act Number 40 of 2007 concerning Limited Liability Companies, Statute Book of 2007 (hereinafter abbreviated as Act of PT ) as lex generalis. Article 1 number (1) of the BUMN Law states that BUMN is a business entity who's entire or most of its capital is owned by the state through direct participation from separated state assets. SOEs here include Persero and Public Companies (Perum) and other Limited Liability Companies (PT) (Mulhadi, 2010).

Bearing in mind that SOEs are proven by the inclusion of capital in place and being deposited, each stateowned SOE has at least 51\% of shares, as affirmed in Law Number 19 of 2003 Concerning State-Owned Enterprises (hereinafter abbreviated as BUMN Act) under Article 1 point (2 ) emphasized that "the Company, hereinafter referred to as Persero, is a BUMN in the form of a limited liability company whose capital is divided into shares which are all or at least $51 \%$ (fifty one percent) of its shares owned by the Republic of Indonesia whose main purpose is to pursue profit." thus, making the government a controlling shareholder. In his book entitled Company Law, Stephen W. Mayson, Derek French, and Christopher Ryan stated that a company is said to be a controlling shareholder of another company if the company has more than half of the total nominal value of shares issued by another company, or if the company has the authority to determine the composition of the Directors of another company (Stephen.dkk, 1989).

\subsection{Holding of State-Owned Enterprises}

Considering the various limitations, so the purpose and objective of establishing a BUMN cannot be realized optimally. Likewise, SOEs, both as pioneers / pioneers and as a counterweight to the power of the large 
private sector, have not yet been fully implemented (Choiri, 2003). When structurally BUMN have ceased to be a welfare supplement, the nation began to be heavily influenced by private production activities (Anoraga, 1995). In addition, the management of most SOEs is inefficient so that they suffer losses and become a burden on the country's finances. This is due to the blurring of the legal status and organizational structure of the BUMN itself. In the uncertainty whether SOEs as economic actors who have full autonomy or only as executors or part of the organizational structure of a department (Diah, 2003). Therefore, the idea of the government to restructure came up by forming a BUMN holding. Related to this, Patrick A Gaughan in his book "Mergers, Acquistitions, and Corporate Restructurings", states (Patrick, et al, 2002):

"Rather than a merger or an acquistition, the acquirings company may choose to purchase only a portion of the target's stock and act like a holding company, which is a company that owns sufficient stock to have to have controlling interest in the target".

The existence of a holding company refers to the business reality of the merging of companies under the control of the parent company. The parent company acts as the central leader, directing the business activities of the subsidiary to support the economic interests of the Holding Company as an economic unit (Sulistiowati, 2013). BUMN holding gives birth to subsidiaries under the control of BUMN, such as PT Pupuk Sriwijaya (Persero) Tbk and PT Semen Indonesia (Persero) Tbk are examples of BUMN holding.

Article 1 number (2) SOE Ministerial Regulation No. PER-03 / MBU / 2012 of 2012 concerning Guidelines for Appointment of Members of the Board of Directors and Board of Commissioners of Subsidiaries of State-Owned Enterprises states that "SOE Subsidiaries are limited liability companies, the majority of whose shares are owned by SOEs or limited companies controlled by SOEs". While the legal relationship that arises between the parent company and its subsidiaries is a relationship between shareholders. The implication is that a company can be controlled by another company, even though it has the status as an independent legal subject.

\subsection{Procurement of Goods and Services of Subsidiaries of BUMN}

The procurement of goods and services for SOE subsidiaries has been regulated in such a way through the SOE synergy program beginning with SOE Ministerial Regulation Number 05 / MBU / 2008 concerning General Guidelines for the Implementation of SOE Goods and Services Procurement (hereinafter abbreviated as BUMN SOE Goods and Services 2008). Then followed by the Circular of the Minister of SOE No. SE-03 / MBU.S / 2009 (hereinafter abbreviated as SE Goods and Services 2009). Where Article 2 paragraph (4) confirms that the Users of Goods and Services prioritize the synergy between SOEs and / or Subsidiaries as long as the said goods and services are the products of the BUMN and / or Subsidiaries concerned, and as long as the quality, price and objectives can be accounted for. Then Article 13 paragraph (2) affirmed that the BUMN Directors are required to prepare internal provisions (Standard Operationing and Procedure) for the implementation of the Procurement of Goods and Services, including refutation procedures based on this SOE State Ministerial Regulation.

In the context of carrying out the provisions of Article 13 paragraph (2) of the Goods and Services Candy, the BUMN Directors based on their authority which is also granted by the Law on PT stipulates the Directors' Decree which contains the Guidelines for Procurement of Goods and Services in each SOE. As in PT Pertamina (Persero) where the Board of Directors of PT Pertamina (Persero) established a Directors Decree Number Kpts-51 / C00000 / 2010-SO dated November 29, 2010 concerning Management of Procurement of Goods / Services (SK-051) which contained several provisions relating to the appointment directly a subsidiary as a Pertamina business partner. One of the general policies that apply in Pertamina's environment is to prioritize synergies with other SOEs and / or Subsidiaries as long as the goods and services are the products of other SOEs and / or Business Entity, and as long as the quality, price and objectives can be accounted for.

Regarding BUMN synergy as stipulated in SE BUMN No. 3/2009, several work projects within Pertamina have implemented the principle of synergy with its subsidiaries. One of them is a project to provide security services for workers in Pertamina throughout Indonesia. Pertamina directly appoints its subsidiary, Pertamina Training and Consulting (PTC). However, after the issuance of BUMN Regulation No. 15 of 2012 related to the guidelines for the procurement of goods and services, there is an expansion of its 
application as referred to in Article 12A paragraph (1) stating that "This Ministerial Regulation of the StateOwned Enterprises, shall also be applied to SOE Subsidiaries and SOE Affiliated Companies, the implementation of which is carried out in accordance with the provisions of the legislation. "

When analyzed, the basis for applying it to subsidiaries and SOE affiliated companies is based on CHAPTER VA BUMN Regulation No. 15 of 2012 emphasizing that:

"This Ministerial Regulation is issued by the Minister of State-Owned Enterprises in his position as General Meeting of Shareholders (GMS) for SOEs whose entire shares (100\%) are owned by the Republic of Indonesia and in his position as shareholders for SOEs or limited liability companies whose shares are partially owned by the State, and in his position as the owner of capital in a Public Corporation (Perum)."

The impact of the enactment of this SOE Ministerial Regulation on the nature of subsidiaries and BUMN affiliated companies as independent legal subjects is biased in the SOE holding scheme. This is because the government likens the treatment between SOEs and SOE subsidiaries as regulated in Article 2A paragraph 7 of Government Regulation Number 72 of 2016 concerning amendments to Government Regulation Number 44 of 2005 relating to the Procedure for the Realization and Administration of State Capital in SOEs and limited liability companies along with their explanations. On the other hand, the appointment of directors and commissioners of SOE subsidiaries by SOEs must obtain Government approval (SOEs Minister) as contained in Article 14 of BUMN Regulation No. 3/2012.

Thus the view that states that the legal independence of the subsidiary is very reasonable, because there are differences in understanding among law enforcement agencies related to the legal entity of the subsidiary. In the case of normative legal status of the subsidiary remains a separate legal entity or separate legal entity (Sulistiowati, 2013). This can be seen in the decision of the Supreme Court which recognizes the specificities that make the juridical boundaries that separate the parent and subsidiary companies in the holding company construction blurred. One of them is the Supreme Court Decision Number $1038 \mathrm{~K} /$ PDT.SUS / 2010. Starting with the bankruptcy of PT Cemerlang Selaras Wood Working. Chuan Soon Huat Industrial Group, Ltd. as the parent and creditor demanded payment of the debt of PT Cemerlang Slearas Wood Working to Chuan Soon Huat Industrial Group Ltd as a deduction from the value of bills to other creditors. The Panel of Judges is of the opinion that the position of PT Cemerlang Selaras Wood Working as a subsidiary that does not carry out sales transactions to other parties, except to Chuan Soon Huat Industrial Group, Ltd as the holding company which results in a breakthrough of limited liability from the shareholders of a company, as stipulated in Article 3 paragraph (2) letter (b) of the Law on PT. The consequence is that Chuan Soon Huat Industrial Group, Ltd. has shared the debt of PT Cemerlang Selaras Wood Working.

In another decision, where the Panel of Judges of the Bontang District Court with the defendant Rukasah Darajat Former Technical Director of PT Pupuk East Kalimantan who was acquitted on charges stated that the directors of PT Pupuk Kalimantan Timur which is a subsidiary of PT Pupuk Sriwijaya (Persero) Tbk had harmed state finances. However, a panel of judges stated in one of their considerations that PT Pupuk Kalimantan Timur was not an SOE as stipulated in the State's financial definition in a general explanation of the Corruption Law.

The understanding of the panel of judges related to the Minister of SOEs acting on behalf of the State as BUMN shareholders as affirmed Article 1 paragraph (1) of the BUMN Law still varies. Therefore, it needs to be emphasized that the Minister of SOEs can only set policies towards SOEs. Thus BUMN is only a shareholder in a SOE Subsidiary as contained in Article 1 number (2) BUMN Candy No. 3 of 2012, so that the enactment of the Minister Regulation to SOE Subsidiary by the Minister of SOEs in his capacity as a BUMN shareholder as contained in Chapter VA BUMN Minister Regulation Number 15 of 2012 is an ultra vires practice. Therefore, BUMN Regulation No. 15/2012 does not automatically apply to SOE Subsidiaries.

\section{Conclusion}

The essence of the legal position of SOE subsidiaries in the BUMN holding scheme remains as independent legal subjects or separate legal entities that have their respective organs and responsibilities as regulated in the Law of PT. When the SOE Minister acts on behalf of the State, he is the shareholder of SOE as contained in Article 1 paragraph (1) of the BUMN Law. As a shareholder, the Minister of SOEs can only establish policies towards SOEs. Whereas in SOE Subsidiaries, BUMN Minister's capacity cannot be as 
shareholder, because companies in the form of Persero can be owned by individuals and / or legal entities. So that the provisions of Article 1 number (2) SOE Ministerial Regulation Number 3 of 2012 whereby the Minister of BUMN cannot act as a shareholder. The enactment of BUMN Ministerial Regulation 15/2012 to SOE Subsidiaries by SOEs Minister in his capacity as BUMN shareholder is an ultra vires action.

\section{References}

\section{Books}

[1.] Sulistiowati. 2013. (2) Tanggung Jawab Hukum pada Perusahaan Grup di Indonesia. Jakarta: Penerbit Erlangga.

[2.] Effendi Choiri. 2003. Privatisasi versus Neo Sosialisme. Jakarta; LPES.

[3.] Gunarto Suhardi. 2007. Revitalisasi BUMN. Yogyakarta: penerbit Universitas Atma Jaya Yogyakarta.

[4.] Marwah M. Diah. 2003. Restrukturisasi BUMN di Indonesia. Jakarta: Literata Lintas Media.

[5.] Mulhadi. 2010. Hukum Perusahaan Bentuk-Bentuk Badan Usaha di Indonesia. Bogor: Ghalia Indonesia.

[6.] Munir Fuady. 2005. Pengantar Hukum Bisnis Menata Bisnis Modern di Era global. Bandung: PT Citra Aditya Bakti.

[7.] Pandji Anoraga. 1995. BUMN Swasta dan Koperasi Tiga Pelaku Ekonomi. Jakarta: PT Dunia Pustaka Jaya.

[8.] Patrick A. Gaughan. 2002. Megers, Acquistions, and Corporate Restructurings. Canada: Jhon Willey \& Sons, Inc.

[9.] Ridwan HR. 2006. Hukum Administrasi Negara. Jakarta: RajaGrafindo Persada.

[10.] Stephen W. Mayson, Derek French and Christoper Ryan. 1989. Company Law. sixth edition. London: Blackstone Press Limited.

[11.] Tumbuan, Fred B. G. "Mencermati Kewenangan dan Tanggung jawab Direksi, Komisaris dan Pemegang Saham Menurut Undang-Undang No 1 Tahun 1995", Makalah dalam Prosiding Rangkaian Lokakarya Terbatas Masalah-Masalah Kepailitan dan Wawasan Hukum Bisnis Lainnya, tahun 2004 : Perseroan Terbatas dan Good Coporate Governance, cetakan ketiga, (Jakarta, Pusat Pengkajian Hukum, 2006)

\section{Regulations}

Indonesia, the 1945 Constitution

Indonesia, Law Number 17 of 2003 concerning State Finance

Indonesia, Law Number 19 of 2003 concerning State-Owned Enterprises

Indonesia, Law Number 40 of 2007 concerning Limited Liability Companies

Indonesia, Government Regulation Number 72 of 2016 concerning amendments to Government Regulation Number 44 of 2005 relating to the Procedure for Statements and Administration of State Capital in SOEs and limited liability companies.

Indonesia, SOE Minister of State Regulation No. PER-03 / MBU / 2012 of 2012 concerning guidelines for appointment of Members of the Board of Directors and Board of Commissioners of Subsidiaries of StateOwned Enterprises.

Indonesia, Regulation of the Minister of State-Owned Enterprises Number: PER-15 / MBU / 2012 Regarding Amendments to the Regulation of the Minister of State-Owned Enterprises Number PER-05 / MBU / 2008 concerning General Guidelines for the Implementation of Procurement of Goods and Services of State-Owned Enterprises.

Decision No. 131 / Pid.B / 2010 / PN.BTG on 7 June 2011

Indonesia, SOE Minister Circular Number SE-03 / MBU.S / 2009

http://www.republik.co.id/berita/beraking-newa/ekonomi/11/01/02/155887-pusri-resmi-jadi-holding-bumnpupuk> 
https://semenindonesia.com/anak-perusahaan-dan-afiliasi/

https://www.mahkamahagung.go.id/id/keputusan/3695 